\title{
Heavy metal pollution increases soil microbial carbon limitation: Evidence from ecological enzyme stoichiometry
}

\author{
Mingzhe $\mathrm{Xu}^{1,2}$, Yongxing Cui ${ }^{1,2}$, Jingzi Beiyuan $^{3}$, Xia Wang $^{1,2}$, Chengjiao Duan ${ }^{1,2}$, Linchuan Fang $^{1,4, *}$ \\ 1 State Key Laboratory of Soil Erosion and Dryland Farming on the Loess Plateau, Institute of Soil and Water Conservation, \\ Chinese Academy of Sciences, Ministry of Water Resources, Yangling 712100, China \\ 2 University of Chinese Academy of Sciences, Beijing 100049, China \\ 3 School of Environment and Chemical Engineering, Foshan University, Foshan 528000, China \\ 4 CAS Center for Excellence in Quaternary Science and Global Change, Chinese Academy of Sciences, Xi'an 710061, China
}

H I G H L I G H T S

- The microbial metabolism was limited by soil carbon (C) and phosphorus (P) under heavy metal stress.

- The increase of heavy metal concentration significantly increased the microbial $C$ limitation.

- Heavy metal pollution can increase the loss of soil $\mathrm{C}$ by affecting microbial metabolism.

- Microbial metabolism limitation can be used as a potential index to evaluate the toxicity of heavy metals.

\section{ARTICLE INFO}

Article history:

Received December 14, 2020

Revised March 23, 2021

Accepted April 17, 2021

Keywords:

Heavy metal contamination

Microbial metabolisms

Ecoenzymatic stoichiometry

Soil nutrient limitation
GRAPHICAL ABSTRACT

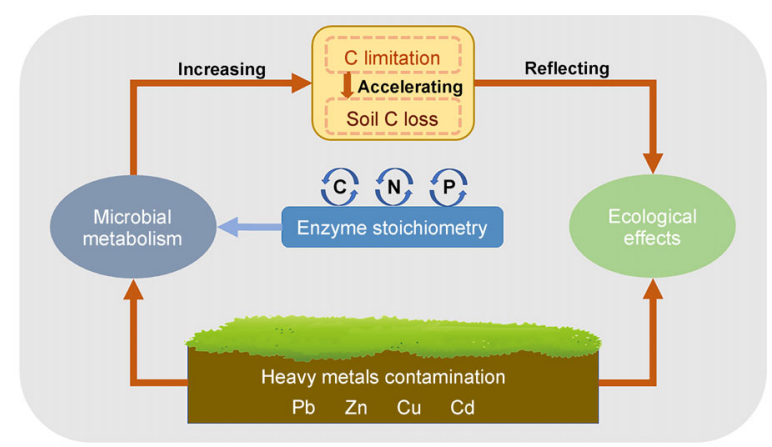

A B S T R A C T

Heavy metals can exist in soil for a long time and seriously affect soil quality. The coexistence of various heavy metal pollutants leads to biotoxicity and alters the activity of microorganisms. Soil microbial metabolism plays an important role in nutrient cycling and biochemical processes of soil ecosystem. However, the effects of heavy metal contamination on microbial metabolism in soil are still unclear. This study aims to reveal the responses of microbial metabolic limitation to heavy metals using extracellular enzyme stoichiometry, and further to evaluate the potential impacts of heavy metal pollution on soil nutrient cycle. The results showed that soil microbial metabolism reflected by the ecoenzymatic activities had a significant response to soil heavy metals pollution. The metabolism was limited by soil carbon $(C)$ and phosphorus $(P)$ under varied heavy metal levels, and the increase of heavy metal concentration significantly increased the microbial $C$ limitation, while had no effect on microbial P limitation. Microorganisms may increase the energy investment in metabolism to resist heavy metal stress and thus induce $C$ release. The results suggest that energy metabolism selected by microorganisms in response to long-term heavy metal stress could increase soil $\mathrm{C}$ release, which is not conducive to the soil $\mathrm{C}$ sequestration. Our study emphasizes that ecoenzymatic stoichiometry could be a promising methodology for evaluating the toxicity of heavy metal pollution and its ecological effects on nutrient cycling.

(c) Higher Education Press 2021
* Corresponding author

E-mail address: flinc629@hotmail.com (L. Fang)

\section{Introduction}

As one of non-biodegradable stress factors to plants, heavy metals can exist in soil for a long time, which may have lasting and harmful effects on soil environment (Xiao et al., 2017; 
Tang et al., 2019). Due to their persistence, soil pollution caused by the heavy metals, has become one of the main problems that endanger the global environmental quality and survival and development of human beings (Yang et al., 2016; Beiyuan et al., 2020). Moreover, it has been confirmed that $\mathrm{Ni}$, $\mathrm{Cd}, \mathrm{Pb}, \mathrm{Cu}, \mathrm{As}, \mathrm{Zn}, \mathrm{Cr}$, and $\mathrm{Hg}$ have toxic effects on soil microorganisms worldwide (Mierzwa-Hersztek et al., 2018; Lin et al., 2019). Microorganisms play a key role in the maintenance of soil ecosystem function and ease the toxicity caused by heavy metals (Stuczynski et al., 2003). They can also enhance their adaptability to the external environment by regulating their own biomass, enzyme activities, and population composition (Fang et al., 2017). The effects of heavy metals on soil microbial diversity and metabolism were mainly inhibitory (Sheik et al., 2012). The coexistence of various heavy metals in soil alters biotoxicity, inhibits microbial metabolism, and changes community composition (Choppala et al., 2014).

In most cases, heavy metal contamination could adversely affect the inherent community structure and activity of microorganisms in the soil (Zhang et al., 2015). Previous studies have provided compelling evidence for the effects of heavy metals on soil microbial communities by applying a variety of methods (Beattie et al., 2018; Ju et al., 2019). For example, the soil microbial community is remarkably diverse, which has been reduced by more than 1,000 times in moderately heavy metal-contaminated soils, while in severely contaminated soils it may account for only $1 \%$ of the primitive soil (Golebiewski et al., 2014). In polluted soil, Proteobacteria was dominant, and the abundance of Chlorophyta and Mycobacterium increased (Berg et al., 2012). Soil microbial metabolism, which is involved in the decomposition of soil organic matter (SOM) and biogeochemical cycles, plays an important role in maintaining soil function (Sinsabaugh et al., 2009). Microbial metabolism may reflect the effects of heavy metal pollution on soil ecosystem better than its community structure. At present, the specific effects of heavy metal content in soil and the interaction between different heavy metals on soil microbial metabolism are still unclear ( $\mathrm{Li}$ et al., 2017).

Compared with plants and animals in the same environment, microbial metabolism is much more sensitive to the stimulation of heavy metals (Wang et al., 2008). Moreover, in order to adapt to the change of environmental conditions, soil microorganisms may change their energy metabolic strategies by changing their carbon (C) use preferences (Xu et al., 2019). Therefore, microbial metabolism may be used as an indicator to evaluate the degree of heavy metal pollution in soil (Aponte et al., 2020b). However, the research on using soil microbiological activities to evaluate heavy metal pollution is still limited (Tang et al., 2019). Enzyme activities are indicators of soil quality and health because of their sensitivity to heavy metal pollution and their direct correlation with soil $\mathrm{C}$, nitrogen $(\mathrm{N})$, and phosphorus (P) cycles (Aponte et al., 2020a). Xiao et al. (2017) had shown that vanadium (V) in low concentration enhanced urease activity, while it in high concentration inhibited urease activity. Cang et al. (2009) reported that alkaline or acidic phosphatase plays an important role in the decomposition of organic P compounds. However, the consistency of using soil enzyme activities as the evaluation index of soil pollution is poor and even contradictory (Alkorta et al., 2003). For example, Wyszkowska et al. (2006) showed the sequence of enzyme sensitivity was: dehydrogenase>urease>alkaline phosphatase>acid phosphatase in soil contaminated by $\mathrm{Cu}, \mathrm{Zn}, \mathrm{Ni}, \mathrm{Pb}, \mathrm{Cd}$ and $\mathrm{Cr}$. Xian et al. (2015) showed that $\mathrm{As}$ and $\mathrm{Cd}$ did not affect the dehydrogenase activity. Therefore, it is of great significance to evaluate the heavy metal toxicity level of soil microbial metabolism by combining the enzymes representing various microbial metabolisms into a comprehensive index.

Ecoenzymatic stoichiometry can reflect the relationship between microbial metabolism demand and soil nutrient supply (Jones et al., 2009). It includes multiple parameters related to soil enzyme activities into specific microbial metabolism characteristics, which has been widely used to reveal the limitation of microbial metabolism represented by C, N, or P (Cui et al., 2018). To identify the characteristics of microbial metabolism, Moorhead et al. (2016) proposed to calculate the "length" and "angle" of the vector in the enzymatic $\mathrm{C}: \mathrm{N}$ versus $\mathrm{C}: \mathrm{P}$ acquisition activity ratio graph to quantify the relative investment in $C$ versus nutrient acquisition (vector length) or $\mathrm{P}$ versus $\mathrm{N}$ acquisition (vector angle). The ratios determine the simultaneous and relative nutrient requirements of microorganisms independent of changes in total enzyme activity (Peng and Wang, 2016). As a result, this method could be promising to elucidate the metabolic response of microorganisms at different heavy metal concentrations.

In the present study, to investigate the response of microbial metabolic limitation to heavy metal types and pollution levels and the potential impact of those pollution on soil nutrient cycling, we carried out a four-year field experiment that includes a series of heavy metal concentration gradients in one of the four largest $\mathrm{Pb}-\mathrm{Zn}$ mines in China. We hypothesized that: (1) soil heavy metal contamination may increase microbial metabolic limitation due to the negative effects of heavy metals on the soil environment; (2) long-term heavy metal pollution may increase soil $\mathrm{C}$ emissions because the microorganisms could improve their adaptability to metal toxicity by increasing the use of $\mathrm{C}$; and (3) microbial metabolism limitation could be used as a sensitive index to evaluate the pollution degree of heavy metals in soil because it incorporates multiple parameters relevant to microbial metabolisms.

\section{Materials and methods}

\subsection{Site description}

The soil sampling area was located near the $\mathrm{Pb}-\mathrm{Zn}$ mine in Feng County, Shaanxi Province, China (approximately 
$106^{\circ} 24^{\prime}-107^{\circ} 07^{\prime} \mathrm{E}, 33^{\circ} 34^{\prime}-34^{\circ} 18^{\prime} \mathrm{N}$ ), which is one of the four largest $\mathrm{Pb}-\mathrm{Zn}$ mines in China (Fang et al., 2017). Feng County has an altitude from 915 to $2937 \mathrm{~m}$. It has a warm temperate semiarid climate with an average annual temperature of $11.3^{\circ}$ $\mathrm{C}$ and annual precipitation of $634.6 \mathrm{~mm}$ (Shen et al., 2017). The reserves of $\mathrm{Pb}-\mathrm{Zn}$ mineral resources in Feng County are about 4.5 million tons. The township industries mainly engaged in $\mathrm{Pb}-\mathrm{Zn}$ mining and mineral processing have developed on a large scale (Xiao et al., 2018). In the process of development of the mine, large amounts of waste residue, tailings and wastewater containing heavy metals were discharged, which polluted the environment.

\subsection{Experimental design and treatments}

In this study, soil pollution levels in the surrounding areas of Dongling $\mathrm{Pb}-\mathrm{Zn}$ smelter were investigated. Soil samples were collected in June 2014. Starting from the location of the chimney of Dongling $\mathrm{Pb}-\mathrm{Zn}$ smelter, sampling points were selected every $300 \mathrm{~m}$. A total of 6 sampling points were selected, with the farthest sampling point being $1800 \mathrm{~m}$ away from the smelter chimney. There were a series of heavy metal concentration gradients due to the distance. These plots had similar slopes, gradients, and altitudes. We randomly established three to four quadrats in each plot before soil sampling. The "S" shape pattern sampling was used in each plot and all the samples collected from each pot were mixed into a composite sample. After thoroughly removed plants and garbage from the soil surface, a clean shovel was used to collect samples from 0 to 20 $\mathrm{cm}$ of topsoil. Each soil sample was further divided into two subsamples after removing debris. The first subsamples were stored in an ice box onsite and then stored at $4 \mathrm{vC}$ in a laboratory to determine extracellular enzyme activities. The second subsamples were screened by a 2-mm mesh and then airdried to analyze their physicochemical properties. Soil bulk density was determined by the core method (Vanremortel and Shields, 1993).

\subsection{Soil physiochemical analysis}

The following soil characteristics of each site were examined: $\mathrm{pH}$, soil organic carbon (SOC), total nitrogen (TN), total phosphorus (TP), available phosphorus (Olsen-P), and soil moisture. Soil pH was measured using a compound electrode (InsMark ${ }^{\mathrm{TM}}$ IS126, Shanghai, China) in a 1:2.5 mass/volume soil-water suspension. Soil moisture content was determined by oven-drying $15 \mathrm{~g}$ of fresh soil at $105^{\circ} \mathrm{C}$ for $48 \mathrm{~h}$. The SOC was determined using dichromate oxidation (Komy, 1995). The TN was determined by the Kjeldahl method after $\mathrm{H}_{2} \mathrm{SO}_{4}-$ $\mathrm{H}_{2} \mathrm{O}_{2}$ digestion (Bremner and Mulvaney, 1996). The TP was measured by an ultraviolet spectrophotometer (Hitachi UV2300) after extracted by $\mathrm{H}_{2} \mathrm{SO}_{4}-\mathrm{HClO}_{4}$. Olsen-P was extracted by $0.5 \mathrm{~mol} \mathrm{~L}^{-1} \mathrm{NaHCO}_{3}$ solution and determined using the molybdenum blue method at $710 \mathrm{~nm}$ (Page et al., 1982).

\subsection{Determining heavy metal in soil}

The total contents of $\mathrm{Cd}, \mathrm{Pb}, \mathrm{Zn}$, and $\mathrm{Cu}$ in soil were determined according to the methods of the United States Environmental Protection Agency (USEPA 2007). A proportion of $0.300 \mathrm{~g}$ of soil sample was added into a tube, then added $10 \mathrm{~mL}$ of mixed acid $\left(\mathrm{HNO}_{3}: \mathrm{HClO}_{4}(\mathrm{v} / \mathrm{v})=4: 1\right)$. After waiting for $24 \mathrm{~h}$, the samples were added $5 \mathrm{~mL}$ concentrated $\mathrm{HCl}$ and shaken well. Then the samples were carefully heated to a constant volume before analyses by an atomic absorption spectrophotometer (FAAS, Hitachi Z-2000).

\subsection{Assays of extracellular enzymatic activity}

The activities of $C$-acquiring enzymes ( $\beta$-1,4-glucosidase $(B G)$ and $\beta$-D-cellobiosidase (CBH)), $N$-acquiring enzymes ( $\beta$-1,4-N-acetylglucosaminidase (NAG) and L-leucine aminopeptidase (LAP)), and P-acquiring enzyme (alkaline phosphatase (AP)) were measured using an improved version of the standard fluorescence assay technique (Saiya-Cork et al., 2002). Specifically, the assays of the five types of soil enzymatic activities were measured using a 96-well plate by eight repeat wells per sample. The analysis included eight duplicate holes for each blank, a negative control, and a quenching standard. Fluorescence measurements of extracellular enzyme activities were measured in $200 \mu \mathrm{M}$ substrates solution using 4-methylumbelliferone (MUB) or 7amino-4-methyl coumarin (AMC). $50 \mu \mathrm{L}$ of $50 \mathrm{mM}$ buffer were dispensed into a black 96-well microplates with pipette to serve as the blanks (buffer + slurry). $200 \mu \mathrm{L}$ of $50 \mathrm{mM}$ buffer were dispensed into the wells as a reference standard (buffer + standard) and a negative control (buffer + substrate). One gram of previously defrosted soil was homogenized in a shaker with constant temperature for $2 \mathrm{~h}$ and placed in $125 \mathrm{~mL}$ of $50 \mathrm{mM}$ buffer. The soil suspension was continuously stirred as $200 \mu \mathrm{L}$ aliquots and dropped into the micropore wells that served as sample assay, blank and quenching standard (slurry + standard). Finally, $25 \mu \mathrm{L}$ of the sample assays (slurry + substrate) and the negative controls (buffer + substrate) were also taken from the $200 \mu \mathrm{M}$ substrate solution, with a final reaction volume of $125 \mu \mathrm{L}$. The prepared plates were incubated in darkness at $25^{\circ} \mathrm{C}$ for $4 \mathrm{~h}$ after substrate addition. Fluorescence was measured using a microplate reader with $365 \mathrm{~nm}$ excitation and $450 \mathrm{~nm}$ emission filter without $\mathrm{NaOH}$ addition (German et al., 2011). The fluorescence measurements of negative control wells, blank wells and quenched standard wells were corrected. The enzyme activities were expressed as nanomoles of substrate released per hour per gram of dry soil (nmol g ${ }^{-1} \mathrm{~h}^{-1}$ ) (Cui et al., 2019).

\subsection{Assessment of soil pollution}

The single contamination factor $(C F)$ was used to evaluate soil heavy metal pollution, and the calculation formula was as follows: 


$$
C F_{i}=C_{i} / C_{n}
$$

where $C_{i}\left(\mathrm{mg} \mathrm{kg}^{-1}\right)$ is the measured value of heavy metals in samples and $C_{n}\left(\mathrm{mg} \mathrm{kg}^{-1}\right)$ is the average concentration of elements in the standards or control or an unpolluted area (Boamponsem et al., 2010). In this study, the risk screening value of heavy metals in the soil environmental quality risk control standard for soil contamination of agricultural land (GB15618-2018) was used as the background value. The contamination levels ranged from 1 to $6(0=$ none, $1=$ none to moderate, $2=$ moderate, $3=$ moderate to strong, $4=$ strongly polluted, $5=$ strong to very strong and $6=$ very strong). The $C F$ for each heavy metal at each site was calculated to evaluate the contamination level (Yang et al., 2016).

Pollution load index $(P L I)$ was used to evaluate the overall level of soil pollution at the sampling sites, and the formula was as follows:

$$
P L I=\left(C F_{1} \times C F_{2} \times \cdots \times C F_{n}\right)^{1 / n}
$$

where $C F$ is the metal contamination factor and $n$ is the number of samples analyzed in this study. Four pollution levels were defined: no pollution $(P L I<1)$, moderate pollution $(1<P L I<2)$, heavy pollution $(2<P L I<3)$, and extremely heavy pollution $(3<P L I)$ (Liu et al., 2013; Duan et al., 2018).

\subsection{Calculation of microbial nutrient limitation}

We calculated the lengths and angles of the vectors for enzymatic activities in all the data based on untransformed proportional activities (Moorhead et al., 2013). The vector length was calculated as the square root of the sum of the squares of $x$ and $y$, where $x$ represents the relative activities of $C$ vs. $P$ to obtain the enzymes and $y$ represents the relative activities of $\mathrm{C}$ vs. $\mathrm{N}$ to obtain the enzyme (Moorhead et al., 2016), as shown in Eq. (3). The vector angle was calculated as the arctangent of the line from the origin to point $(x, y)$, as shown in Eq. (4).

$$
\begin{gathered}
\text { Length }=\sqrt{x^{2}+y^{2}} \\
\operatorname{Angle}\left({ }^{\circ}\right)-\operatorname{DEGREES}(\operatorname{ATAN} 2(x, y))
\end{gathered}
$$

Microbial C limitation increases with the vector length. When the vector angle greater than $45^{\circ}$, the result represents microbial $P$ limitation; when it less than $45^{\circ}$, the result represents microbial $\mathrm{N}$ limitation. The level of microbial $\mathrm{P}$ limitation increases with the vector angle, while the level of microbial $\mathrm{N}$ limitation decreases with the vector angle (Allison et al., 2010).

\subsection{Statistical analysis}

Significant differences among treatments were tested using one-factor ANOVA followed by the Duncan's multiple comparisons test and the significant differences were accepted at $P<0.05$. The ANOVA analysis was used to analyze the changes of soil physicochemical properties, heavy metal content and limitation of microbial metabolism among different treatments, and the mean values were compared. A generalized linear model was used to determine the relationship between microbial $C$ limitation and microbial $P$ limitation and the correlations between the limitation of microbial metabolism and soil heavy metals contents. The effects of different heavy metals on soil microbial metabolism limitation were analyzed with redundancy analysis (RDA) using CANOCO 5. All the statistical analyses were performed in IBM SPSS version 23.0 (SPSS Inc., Chicago, USA). The graph was drawn using Origin 2020b.

\section{Results}

3.1 Content of heavy metals and physicochemical properties of the soil samples

The total content of $\mathrm{Cu}, \mathrm{Pb}, \mathrm{Zn}$, and $\mathrm{Cd}$ in different soil samples was shown in Fig. 1. The total content of $\mathrm{Cu}, \mathrm{Zn}$ and $\mathrm{Cd}$ gradually increased with the increase of pollution degree which was evaluated by the $P L I$ value (the higher $P L I$ value, the heavy pollution degree). The highest total content of $\mathrm{Zn}$ $\left(2993 \pm 76.27 \mathrm{mg} \mathrm{kg}^{-1}\right)$ and $\mathrm{Pb}\left(239.15 \pm 9.97 \mathrm{mg} \mathrm{kg}^{-1}\right)$ was found in T1. The T3 had the highest contents of $\mathrm{Cd}$ $\left(55.74 \pm 1.56 \mathrm{mg} \mathrm{kg}^{-1}\right)$ and $\mathrm{Cu}\left(93.66 \pm 2.36 \mathrm{mg} \mathrm{kg}^{-1}\right)$, while T6 has the lowest content of $\mathrm{Zn}\left(870 \pm 4.36 \mathrm{mg} \mathrm{kg}^{-1}\right)$, $\mathrm{Pb}\left(56.69 \pm 1.81 \mathrm{mg} \mathrm{kg}^{-1}\right), \mathrm{Cd}\left(7.05 \pm 0.29 \mathrm{mg} \mathrm{kg}^{-1}\right)$ and $\mathrm{Cu}\left(1.48 \pm 0.03 \mathrm{mg} \mathrm{kg}^{-1}\right)$. According to our assessment, all treatments can be divided into three groups: extremely heavy pollution (E; PLI>3): $\mathrm{F} 1-\mathrm{F} 3$, heavy pollution $(\mathrm{H} ; 2<P L I<3)$ : F4-F5, and no pollution (N; $P L I<1)$ : F6 (Table 1). The CF values of $\mathrm{Zn}, \mathrm{Pb}, \mathrm{Cd}$, and $\mathrm{Cu}$ were in ranges of 2.90-9.98, $0.162-0.683,0.015-0.937$ and $11.76-92.91$, respectively. Results showed that there were different degrees of $\mathrm{Cu}, \mathrm{Zn}$, $\mathrm{Cd}$, and $\mathrm{Pb}$ pollution in the sampling area, among which $\mathrm{Cd}$ and $\mathrm{Zn}$ pollution are the most serious.

The physicochemical properties of soil samples were shown in Table 2. The soil samples were weakly alkaline, with an average $\mathrm{pH}$ of 7.95 to 7.77 in the five sampling sites. The T1 has the highest content of SOC $\left(15.3 \pm 0.67 \mathrm{~g} \mathrm{~kg}^{-1}\right)$, TN $\left(1.41 \pm 0.01 \mathrm{~g} \mathrm{~kg}^{-1}\right)$, while T6 has the highest content of dissolved organic carbon (DOC, $100.7 \pm 6.28 \mathrm{mg} \mathrm{kg}^{-1}$ ), dissolved organic nitrogen ( $D O N, 53.78 \pm 2.12 \mathrm{mg} \mathrm{kg}^{-1}$ ), and Olsen-P $\left(16.7 \pm 3.02 \mathrm{mg} \mathrm{kg}^{-1}\right)$. The results of the correlation analysis showed that the Olsen-P was negatively correlated with soil $\mathrm{Cd}, \mathrm{Pb}, \mathrm{Zn}$, and $\mathrm{Cu}$ content in the soil. The concentration of DOC, TP, and Cd were negatively correlated, by contrast, $\mathrm{TN}, \mathrm{SOC}$, and $\mathrm{Pb}$ were positively correlated. The TP was significantly negatively correlated to soil $\mathrm{Cu}$ concentration (Fig. 4).

3.2 Extracellular enzymes activities in the soil samples with varied content of heavy metals

The activities of the five extracellular enzymes were sig- 

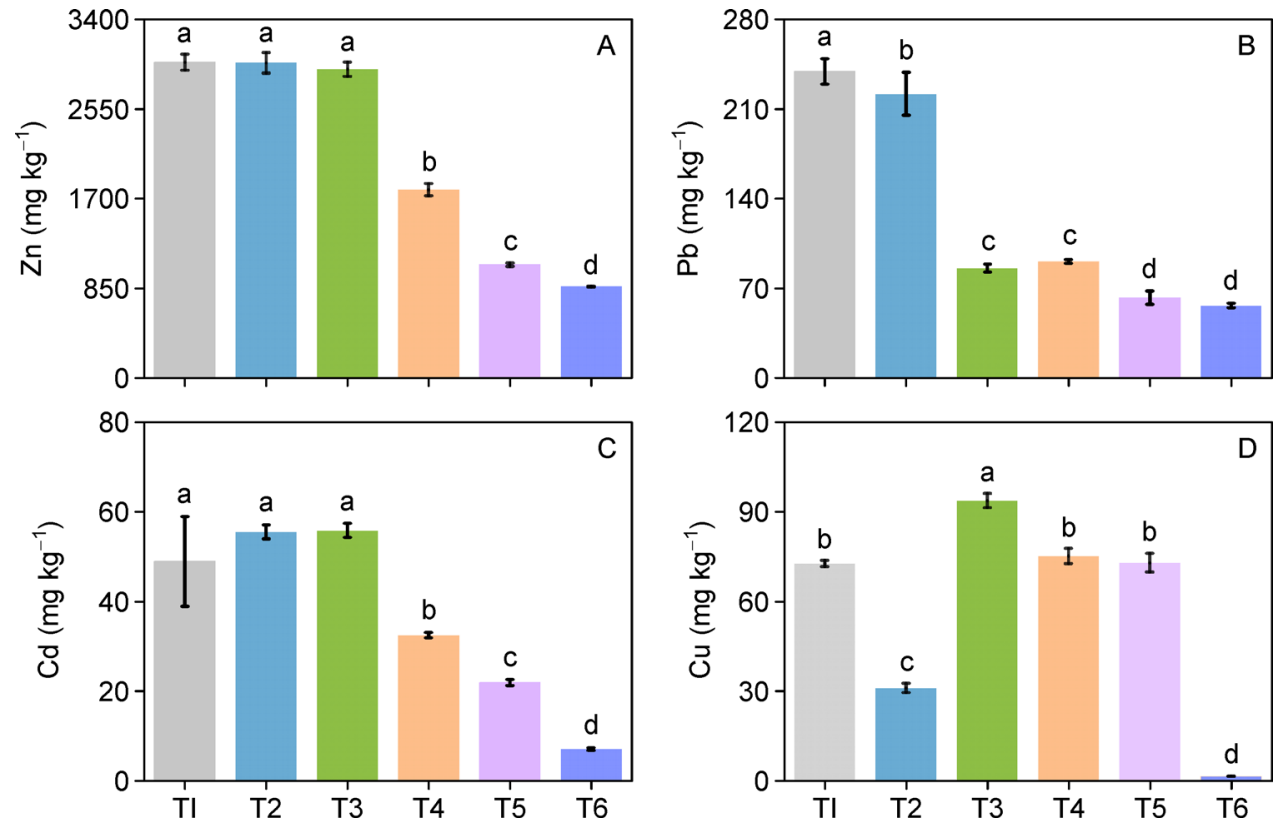

Fig. 1 Changes of soil heavy metal concentrations in sampling sites.

Table 1 Heavy metal pollution assessment by the metals contamination factor (CF) and the level of heavy metal pollution (PLI) in different sites.

\begin{tabular}{|c|c|c|c|c|c|c|}
\hline \multirow[t]{2}{*}{ Sampling sites } & \multicolumn{4}{|c|}{$C F$} & \multirow[t]{2}{*}{ PLI } & \multirow[t]{2}{*}{ Grade } \\
\hline & $\mathrm{Cd}$ & $\mathrm{Pb}$ & $\mathrm{Zn}$ & $\mathrm{Cu}$ & & \\
\hline $\mathrm{T} 1$ & 81.44 & 0.683 & 9.98 & 0.726 & 4.48 & E \\
\hline $\mathrm{T} 2$ & 92.39 & 0.634 & 9.96 & 0.310 & 3.67 & $E$ \\
\hline T3 & 92.91 & 0.246 & 9.76 & 0.937 & 3.80 & E \\
\hline $\mathrm{T} 4$ & 54.07 & 0.260 & 5.95 & 0.751 & 2.82 & $\mathrm{H}$ \\
\hline T5 & 36.40 & 0.179 & 3.59 & 0.728 & 2.03 & $\mathrm{H}$ \\
\hline T6 & 11.76 & 0.162 & 2.90 & 0.015 & 0.54 & $\mathrm{~N}$ \\
\hline
\end{tabular}

Note: $\mathrm{N}$ is no pollution, $\mathrm{M}$ is moderate pollution, $\mathrm{H}$ is heavy pollution, $\mathrm{E}$ is extremely heavy pollution. $\mathrm{PL} /$ reflects the degree of heavy metal pollution in the region.

nificantly affected by the level of heavy metal content in soil $(P<0.05$, Table 3). However, the impacts of increasing heavy metal pollution levels on soil enzymes were not consistent and had enzyme specificity. Compared with different contents of heavy metals in soil, the lowest enzyme activities were obtained in T1: BG $\left(1476.8 \pm 103.3 \mathrm{nmol} \mathrm{SOM}^{-1} \mathrm{~h}^{-1}\right)$, $\mathrm{CBH}\left(396.96 \pm 37.4 \mathrm{nmol} \mathrm{SOM}^{-1} \mathrm{~h}^{-1}\right)$, NAG $(431.5 \pm 35.8$ nmol SOM $\left.{ }^{-1} \mathrm{~h}^{-1}\right)$, LAP $\left(504.2 \pm 37.7 \mathrm{nmol} \mathrm{SOM}^{-1} \mathrm{~h}^{-1}\right)$, and AP $\quad\left(5,574.2 \pm 180.9 \mathrm{nmol} \mathrm{SOM}^{-1} \mathrm{~h}^{-1}\right)$. The highest enzyme activities were found in T6 (BG $(2991.6 \pm 259.6$ $\left.\mathrm{nmol} \mathrm{SOM}{ }^{-1} \mathrm{~h}^{-1}\right)$ and NAG $\left.\left(874.9 \pm 38.3 \mathrm{nmol} \mathrm{SOM}^{-1} \mathrm{~h}^{-1}\right)\right)$.

\subsection{Microbial metabolic characteristics}

All data points were above the $1: 1$ line, indicating that there is $P$ limitation in the microbial community in our study area
(Fig. 2). The relative $C$ and $P$ limitation of microorganisms were quantified by calculating the vector lengths and vector angles (Fig. 3). The vector lengths and angles (ranging from 0.531 to 0.785 and 64.6 to $76.3^{\circ}$, respectively) were significantly affected by the content of heavy metals $(P<0.001)$. Heavy metal pollution significantly affected microbial metabolism. The T2 has the highest $C$ microbial limitation, with the microbial $C$ limitation decreased with the vector length. The T6 has the highest microbial $P$ limitation.

3.4 Effects of the total content of heavy metals and physicochemical properties on microbial metabolism limitation

Linear regression analyses identified that microbial $\mathrm{C}$ limitation was significantly positively correlated to the content of $\mathrm{Cd}$, $\mathrm{Pb}$, and $\mathrm{Zn}$ in soil. However, there was no significant 
Table 2 Physicochemical properties of soil samples collected from different sites.

\begin{tabular}{lllllll}
\hline Sites & T1 & T2 & T3 & T4 & T5 & T6 \\
\hline SOC $\left(\mathrm{g} \mathrm{kg}^{-2}\right)$ & $15.3 \pm 0.67 \mathrm{a}$ & $7.77 \pm 0.33 \mathrm{a}$ & $8.94 \pm 1.15 \mathrm{bc}$ & $9.50 \pm 0.42 \mathrm{~b}$ & $8.33 \pm 0.77 \mathrm{bc}$ & $9.30 \pm 0.05 \mathrm{~b}$ \\
$\mathrm{TN}\left(\mathrm{g} \mathrm{kg}^{-2}\right)$ & $1.41 \pm 0.01 \mathrm{a}$ & $0.93 \pm 0.06 \mathrm{c}$ & $1.01 \pm 0.02 \mathrm{bc}$ & $1.09 \pm 0.01 \mathrm{~b}$ & $0.98 \pm 0.00 \mathrm{bc}$ & $0.92 \pm 0.15 \mathrm{c}$ \\
$\mathrm{TP}\left(\mathrm{g} \mathrm{kg}^{-2}\right)$ & $0.86 \pm 0.02 \mathrm{~b}$ & $0.79 \pm 0.01 \mathrm{bc}$ & $0.69 \pm 0.02 \mathrm{c}$ & $0.71 \pm 0.01 \mathrm{c}$ & $0.78 \pm 0.01 \mathrm{bc}$ & $1.03 \pm 0.15 \mathrm{a}$ \\
$\mathrm{DOC}\left(\mathrm{mg} \mathrm{kg}^{-2}\right)$ & $84.45 \pm 3.61 \mathrm{bc}$ & $77.14 \pm 1.70 \mathrm{c}$ & $87.98 \pm 3.81 \mathrm{~b}$ & $88.44 \pm 3.05 \mathrm{~b}$ & $77.81 \pm 4.98 \mathrm{c}$ & $100.7 \pm 6.28 \mathrm{a}$ \\
DON $\left(\mathrm{mg} \mathrm{kg}^{-2}\right)$ & $50.15 \pm 2.84 \mathrm{ab}$ & $43.25 \pm 0.27 \mathrm{c}$ & $53.85 \pm 1.14 \mathrm{a}$ & $55.16 \pm 1.77 \mathrm{a}$ & $46.44 \pm 5.51 \mathrm{bc}$ & $53.78 \pm 2.12 \mathrm{a}$ \\
Olsen-P $\left(\mathrm{mg} \mathrm{kg}^{-2}\right)$ & $6.58 \pm 0.12 \mathrm{c}$ & $8.95 \pm 0.18 \mathrm{~b}$ & $8.96 \pm 0.07 \mathrm{~b}$ & $9.86 \pm 0.17 \mathrm{~b}$ & $7.73 \pm 0.12 \mathrm{bc}$ & $16.7 \pm 3.02 \mathrm{a}$ \\
Moisture $(\%)$ & $16.2 \pm 0.02 \mathrm{c}$ & $18.6 \pm 0.01 \mathrm{ab}$ & $18.5 \pm 0.01 \mathrm{ab}$ & $19.5 \pm 0.01 \mathrm{a}$ & $17.5 \pm 0.00 \mathrm{abc}$ & $16.5 \pm 0.01 \mathrm{bc}$ \\
pH & $7.95 \pm 0.05 \mathrm{~d}$ & $8.22 \pm 0.03 \mathrm{a}$ & $8.13 \pm 0.02 \mathrm{~b}$ & $8.02 \pm 0.02 \mathrm{c}$ & $8.16 \pm 0.03 \mathrm{~b}$ & $8.14 \pm 0.02 \mathrm{~b}$ \\
\hline
\end{tabular}

Note: Values are means \pm standard error $(n=3)$. Different letters indicate significant differences among based on one-way ANOVA followed by Duncan's test. $(P<0.05)$. SOC, soil organic carbon; TN, soil total nitrogen; TP, soil total phosphorus; DOC, soil dissolved organic carbon; DON, soil dissolved organic nitrogen; Olsen-P, available phosphorus.

Table 3 Enzyme activities of soil samples collected from different sites.

\begin{tabular}{llllll}
\hline $\begin{array}{l}\text { Sampling } \\
\text { sites }\end{array}$ & BG & CBH & NAG & LAP & AP \\
& $\left(\mathrm{nmol} \mathrm{SOM}^{-1} \mathrm{~h}^{-1}\right)$ & $\left(\mathrm{nmol} \mathrm{SOM}^{-1} \mathrm{~h}^{-1}\right)$ & $\left(\mathrm{nmol} \mathrm{SOM}^{-1} \mathrm{~h}^{-1}\right)$ & $\begin{array}{l}\left(\mathrm{nmol} \mathrm{SOM}^{-1} \mathrm{~h}^{-1}\right) \\
\left(\mathrm{nmol} \mathrm{SOM}^{-1} \mathrm{~h}^{-1}\right)\end{array}$ \\
TI & $1476.8 \pm 103.3 \mathrm{c}$ & $396.9 \pm 37.4 \mathrm{ab}$ & $431.5 \pm 35.8 \mathrm{c}$ & $504.2 \pm 37.7 \mathrm{c}$ & $5574.2 \pm 180.9 \mathrm{c}$ \\
T2 & $2042.3 \pm 81.5 \mathrm{~b}$ & $488.7 \pm 50.8 \mathrm{ab}$ & $813.7 \pm 22.0 \mathrm{ab}$ & $407.0 \pm 40.7 \mathrm{~cd}$ & $12947.6 \pm 1205.8 \mathrm{a}$ \\
T3 & $2446.9 \pm 138.8 \mathrm{~b}$ & $525.5 \pm 40.8 \mathrm{a}$ & $623.6 \pm 20.0 \mathrm{abc}$ & $1111.2 \pm 151.7 \mathrm{a}$ & $9967.7 \pm 1357.1 \mathrm{~b}$ \\
T4 & $2030.8 \pm 174.8 \mathrm{~b}$ & $395.4 \pm 14.9 \mathrm{ab}$ & $579.3 \pm 159.3 \mathrm{bc}$ & $822.0 \pm 51.2 \mathrm{~b}$ & $9187.8 \pm 183.3 \mathrm{~b}$ \\
T5 & $1444.9 \pm 79.3 \mathrm{c}$ & $371.7 \pm 39.1 \mathrm{~b}$ & $763.2 \pm 82.2 \mathrm{ab}$ & $1373.0 \pm 119.7 \mathrm{a}$ & $8381.3 \pm 673.8 \mathrm{~b}$ \\
T6 & $2991.6 \pm 259.6 \mathrm{a}$ & $452.6 \pm 46.9 \mathrm{ab}$ & $874.9 \pm 38.3 \mathrm{a}$ & $182.1 \pm 18.7 \mathrm{~d}$ & $9023.6 \pm 575.3 \mathrm{~b}$ \\
\hline
\end{tabular}

Note: Values are means \pm standard error $(n=3)$. Different letters indicate significant differences among based on one-way ANOVA followed by Duncan's test $(P<0.05)$. BG, $\beta$-1,4-glucosidase; CBH, $\beta$-D-cellobiosidase; NAG, $\beta$-1,4-N-acetylglucosaminidase; LAP, L-leucine aminopeptidase; $\mathrm{AP}$, alkaline phosphatase.

correlation of microbial C limitation with soil $\mathrm{Cu}$ (Fig. 4). To better investigate the effects of heavy metal content and soil physicochemical properties on the microbial metabolic limitation, redundant analysis was performed (Fig. 6). Heavy metal content and soil physicochemical properties were environmental variables, while microbial enzymes, vector length and vector angle were species variables. Axis 1 explained $84.3 \%$ of the environment variables, and Axis 2 explained $5.0 \%$ of the environment variables. This can further support that the contents of $\mathrm{Zn}, \mathrm{Pb}$, and $\mathrm{Cd}$ were positively correlated with microbial $C$ limitation (Fig. 5). In addition, Olsen-P, DOC, TP and $\mathrm{pH}$ showed a significant positive correlation with soil microbial metabolism.

\section{Discussion}

4.1 The distinct effects of heavy metals on microbial metabolic limitation in soil

Our results suggested that $\mathrm{Cu}, \mathrm{Pb}, \mathrm{Zn}$, and $\mathrm{Cd}$ can significantly alter the metabolic limitation of microorganisms
(Fig. 3). The scatter diagram of soil enzymatic stoichiometry provided evidence that soil microorganisms were notably limited by $C$ and $P$ (Fig. 2), which is consistent with our first hypothesis. Our study showed that the enzyme activity of T1 which has the highest degree of heavy metal pollution was significantly reduced (Table 3 ). Soil microorganisms are remarkably sensitive to the changes and stresses from soil (Baumann et al., 2012). The key mechanism of metal toxicity to microorganisms is the displacement or substitution of toxic elements in extracellular enzymes or even in nuclear proteins, which leads to enzyme synthesis inhibition and metabolic process dysfunction (Xu et al., 2018). Therefore, toxic levels of heavy metals may reduce soil microbial activities by altering protein structure and damaging cell membrane function (Oliveira and Pampulha, 2006). The increase of heavy metals in microbial cells resulted in denaturation of enzyme protein (Markowicz et al., 2016). Heavy metals interact with amino acid residues at active sites catalyzed by enzymes or react with substrate complexes, resulting in decreased enzyme activities (Kuperman and Carreiro, 1997). However, the interaction between soil microorganisms and heavy metals 


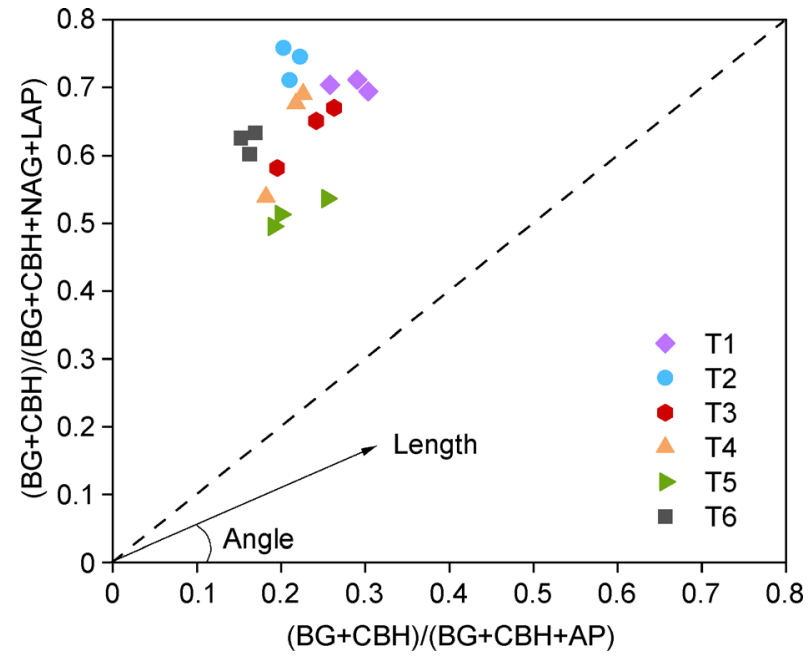

Fig. 2 Ecoenzymatic stoichiometry of the relative proportions of $\mathrm{C}$ to $\mathrm{N}$ acquisition versus $\mathrm{C}$ to $\mathrm{P}$ acquisition.

can affect the metal functional groups (Hu et al., 2014). For example, leading to metal mobilization, dissolution, leaching, and redox transformation. Soil microorganisms can also immobilize organo-metals via binding and precipitation (Xu et al., 2019). Therefore, the increase of soil heavy metal content could affect or even inhibit the growth and metabolic activities of microorganisms.

The vector length of T1-T6 showed a decreasing trend, suggesting that heavy metal pollution has a positive impact on the microbial $C$ limitation (0.531-0.785) (Fig. 3). Moreover, different heavy metals ( $\mathrm{Cd}, \mathrm{Pb}$, and $\mathrm{Zn})$ had consistent effects on microbial $\mathrm{C}$ limitation (Fig. 4). This can be associated with that microbes can accumulate heavy metals by either adsorption or absorption (Bore et al., 2017). Previous studies have shown that the main mechanism of microbial accumulation of heavy metal ions is adsorption (Wang et al., 2001). Adsorption involves complexing heavy metals on the cell surface where they can be absorbed into the cell. Adsorption hinders the transport and absorption process of electrons and substances, which is largely dependent on energy metabolism (Jin et al., 2018). Moreover, the content of heavy metals affects microbial respiration metabolism (metabolic quotients response) and their activity, thereby altering soil respiration (Frey et al., 2001). Wang et al., (2001) also found that the microbial metabolism quotients of soil heavily polluted by heavy metals was higher, and the proportion of SOC into biological $\mathrm{C}$ decreased. As a result, microorganisms could consume additional $\mathrm{C}$ sources in response to the toxic effects of heavy metals. The low microbial $\mathrm{C}$ limitation reflected low levels of heavy metal contamination and toxicity, while the high microbial $\mathrm{C}$ limitation is the opposite (Fig. 4). Our results also show that the effects of different heavy metals on microbial $\mathrm{C}$ limitation are consistent, which is also confirmed by the association between $P L I$ and microbial metabolic limitation (Fig. 7). These results indicated that the microbial $\mathrm{C}$ limitation could sensitively reflect the direction and degree of soil biochemical reaction, and could thus be used as a potential biological indicator for the soil health diagnosis.

The influence of heavy metal pollution on the $P$ limitation of microorganism has no obvious trend (Fig. 3). Only results from T1-T3 support our hypothesis that heavy metal stress has a negative effect on microbial $P$ limitation (Fig. 3). This may be due to the microorganisms maintain the stability of chemical composition in the body through homeostasis regulation in the face of changes in environmental factors such as heavy metal pollution. Heavy metal ions can increase the release of phosphorus free radicals by competing adsorption sites and adjusting $\mathrm{pH}$ value, thus increasing the available $\mathrm{P}$ in soil (Wang et al., 2020). Microorganisms can obtain element $P$ through the secretion of phosphatase and other pathways (Moorhead et al., 2013). Due to the complexity of soil ecological environment, the regulation mechanism of microbial $\mathrm{P}$ limitation under heavy metal pollution still needs further discussion in the future.

\subsection{Contribution of heavy metal pollution to potential $\mathrm{C}$ loss in soil}

Soil microbial $C$ limitation increased under the influence of heavy metal pollution (Fig. 2). C limitation also indicates high C-acquiring enzyme activities, which may increase the decomposition potential of SOM. The potential impact of
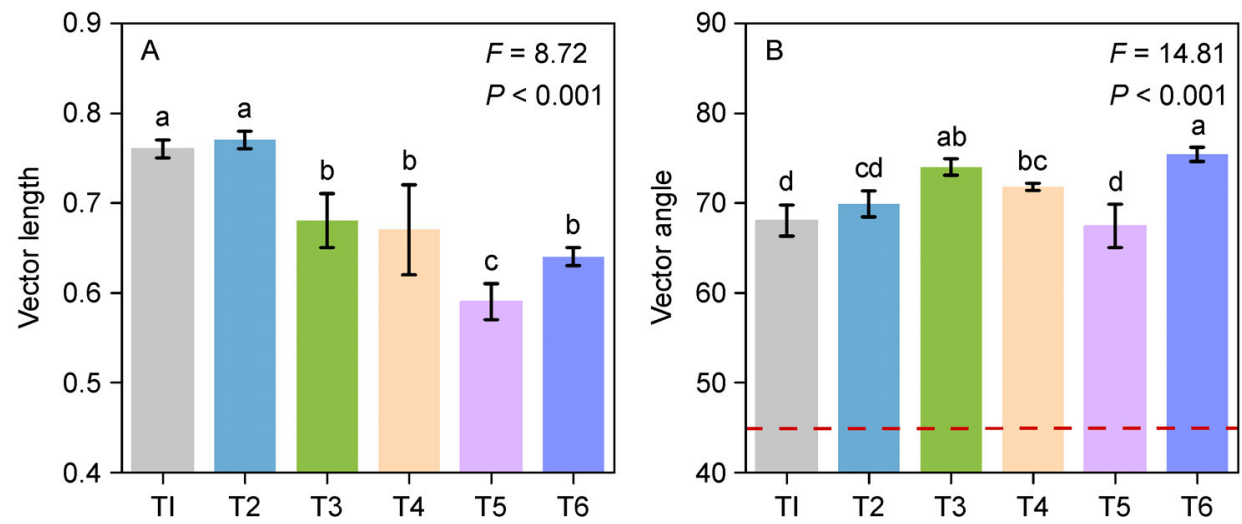

Fig. 3 The variation of the vector length $(A)$ and angle $(B)$ under heavy metal concentration gradient. 

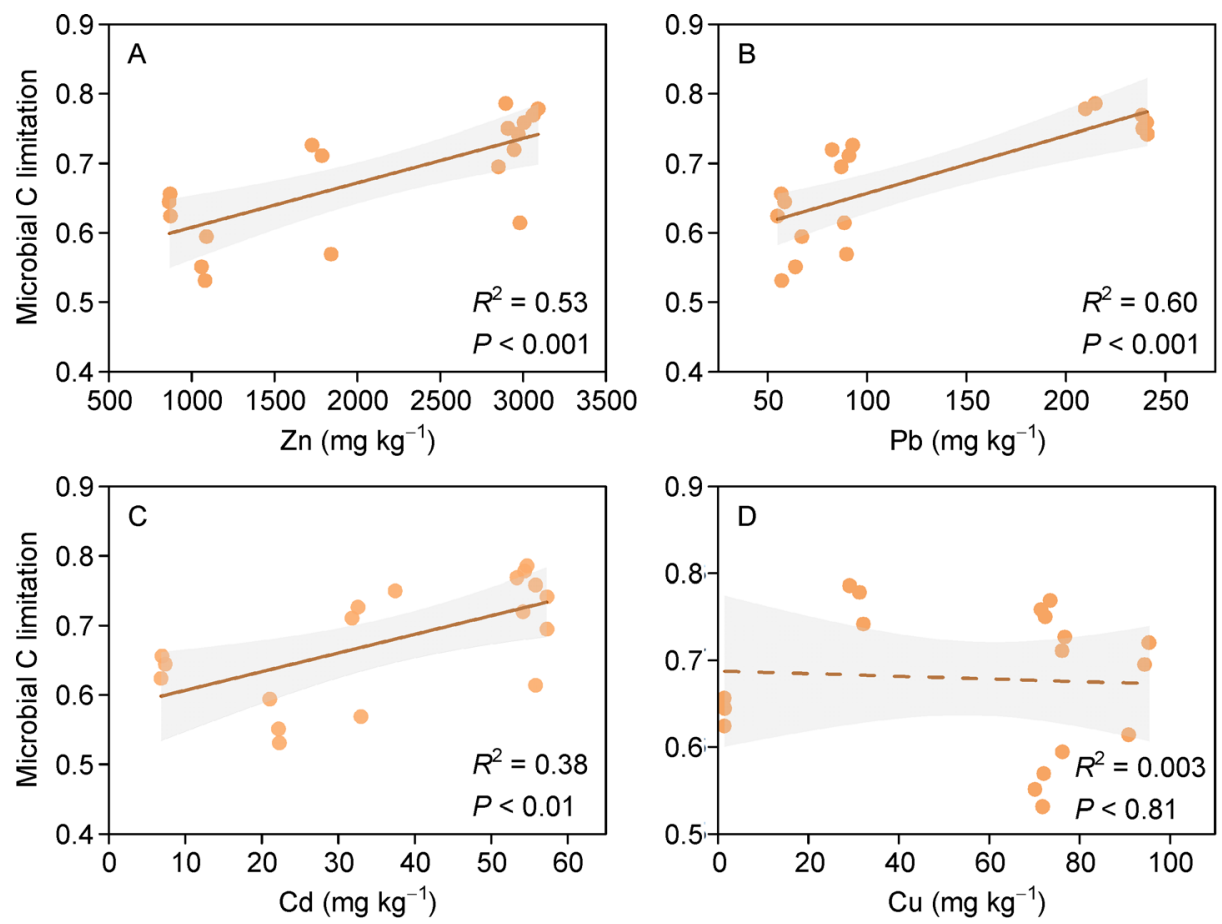

Fig. 4 Relationship between heavy metals $(\mathrm{Zn}, \mathrm{Pb}, \mathrm{Cd}, \mathrm{Cu})$ and microbial $\mathrm{C}$ limitation.

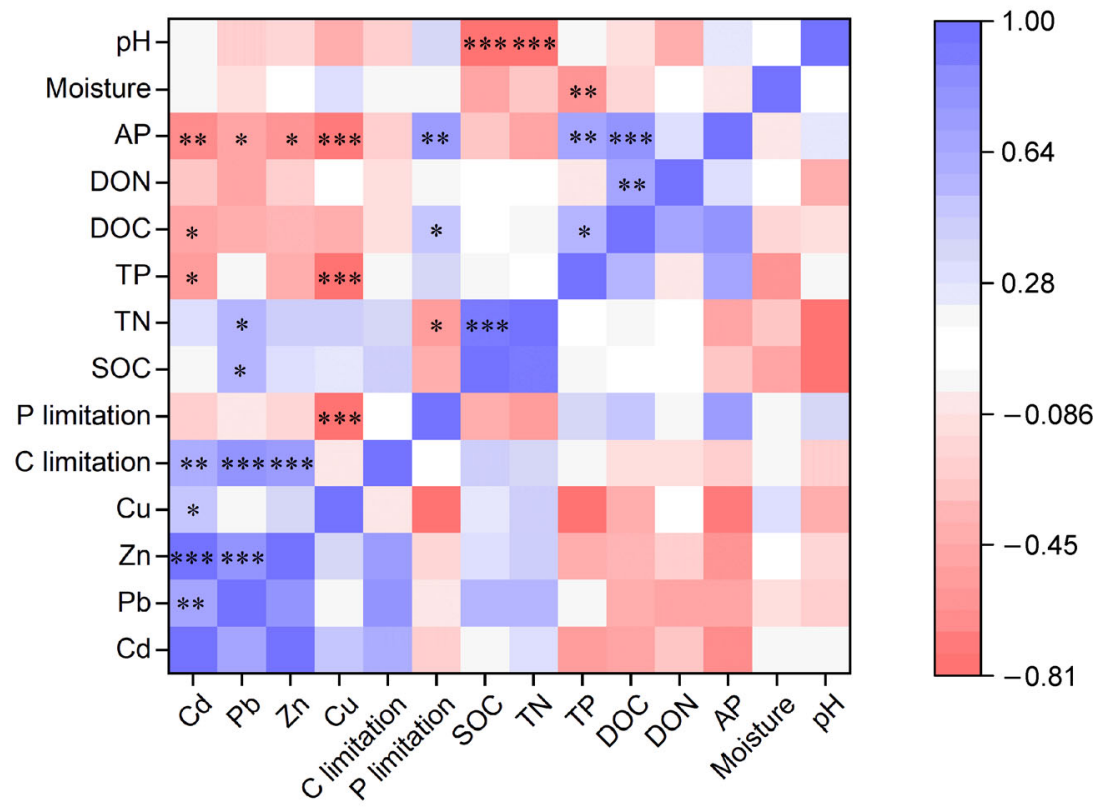

Fig. 5 Heat map of correlations among soil physicochemical properties, heavy metals in soil, and microbial nutrient limitations.

heavy metal pollution on soil ecosystem is significant. Kandeler et al. (2000) found that heavy metals can react with sulfonamides of enzymes, thereby inhibiting their activity or inactivating them. Previous study has found that the inhibition of heavy metals on microbial activity not only results in the release of the total release $\mathrm{CO}_{2}$, but also leads to the reduction of microbial respiration rate (Xu et al., 2019). To resist the effects of heavy metals, certain microorganisms might develop adaptation and tolerance to metal toxicity by altering their $\mathrm{C}$ use preference in the long-term (Khan et al., 2007). Our study showed that DOC decreases with the increase of heavy metal concentration $(77.14 \pm 1.70$ to $100.7 \pm$ $6.28 \mathrm{mg} \mathrm{kg}^{-1}$ ) (Table 2). As a result, these processes will lead to the change of microbial metabolism from growth metabo- 


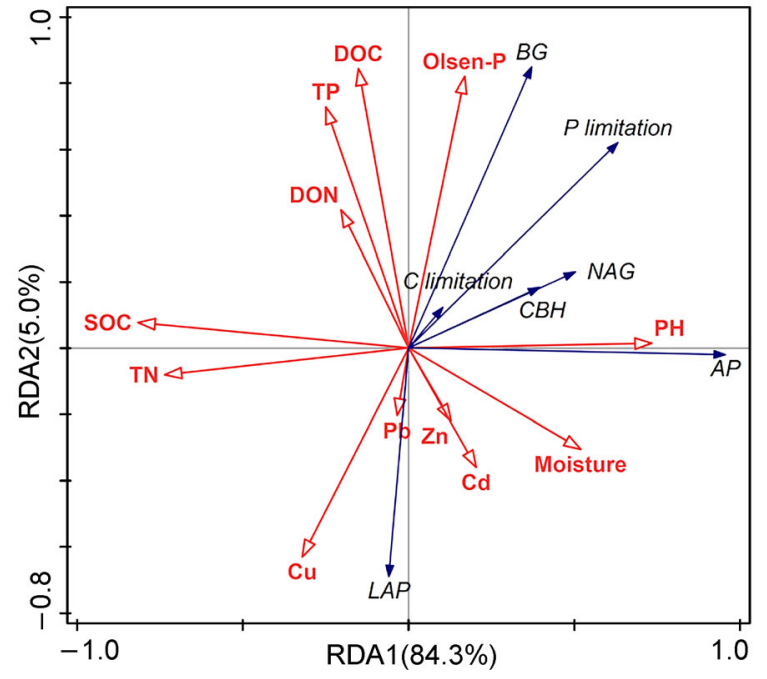

Fig. 6 The relationship between the soil heavy metals, soil physicochemical properties and microbial nutrient limitation evaluated by the redundancy analysis (RDA).

lism to respiration maintenance metabolism, and increase of microbial energy consumption.

Tripathy et al. (2014) reported that the soil microbial quotient (SMQ) which is in the ratio of soil microbial biomass C to total SOC in contaminated soil is lower than that of background soil $(2.60 \%-3.51 \%)$, and a low SMQ represents soil nutrient loss (Chander et al., 2001; Chen et al., 2017). Soil nutrient loss can affect SOM storage. In this process, the enhanced decomposition of organic matter is due to the increase of microbial $C$ limitation. Soil microbial $C$ use efficiency (CUE) refers to the efficiency of microorganisms to convert $\mathrm{C}$ absorbed into their own biomass $\mathrm{C}$ (Blagodatskaya et al., 2014). The CUE can serve as a reference for microbial $C$ use preferences in the soil (Frey et al., 2001). In most cases, CUE is reduced with heavy metal pollution because a higher proportion of $\mathrm{C}$ is absorbed to alleviate heavy metal stress. For example, Xu et al. (2018) reported the reduction of microbial CUE in heavy metal contaminated soil.
The microbial CUE of the soil with $\mathrm{Cd}+\mathrm{Pb}$ was 0.31 , while the CUE of the soil without contamination was 0.41 . In conclusion, microbial metabolism under heavy metal stress with a large area and strong persistence will increase the loss of soil ecosystem C.

\section{Conclusions}

The results showed that the microbial metabolisms were limited by $\mathrm{C}$ and $\mathrm{P}$ in soils contaminated with $\mathrm{Cu}, \mathrm{Pb}, \mathrm{Zn}$, and $\mathrm{Cd}$, and the caused stress significantly increased the microbial $C$ limitation. Changes in microbial metabolic processes under $\mathrm{Cu}, \mathrm{Pb}, \mathrm{Zn}$, and $\mathrm{Cd}$ pollution could will promote the decomposition of soil $\mathrm{C}$ in order to provide more bioavailable C sources for meeting their own metabolic needs, which thus potentially increase the loss of soil C. Moreover, microbial C limitation has a consistent response to different heavy metals (i.e., $\mathrm{Cd}, \mathrm{Pb}$, and $\mathrm{Zn}$ ), indicating that microbial metabolic limitation may be as a promising index for evaluating the effect of combined heavy metal pollution in soils. Future research could use isotope labeling and high-throughput sequencing to expand our understanding of the mechanisms of microbial metabolic limitation induced by heavy metal stress.

\section{Acknowledgments}

This work was financially supported by the Science Foundation for Distinguished Youth of Shaanxi Province (2020JC-31), the National Natural Science Foundation of China (41977031), CAS "Light of West China" Program (XAB2016A03) and Program of State Key Laboratory of Loess and Quaternary Geology CAS (SKLLQGZR1803).

\section{Declaration of competing interest}

The authors declare that they have no known competing financial interests or personal relationships that could have appeared to influence the work reported in this paper.
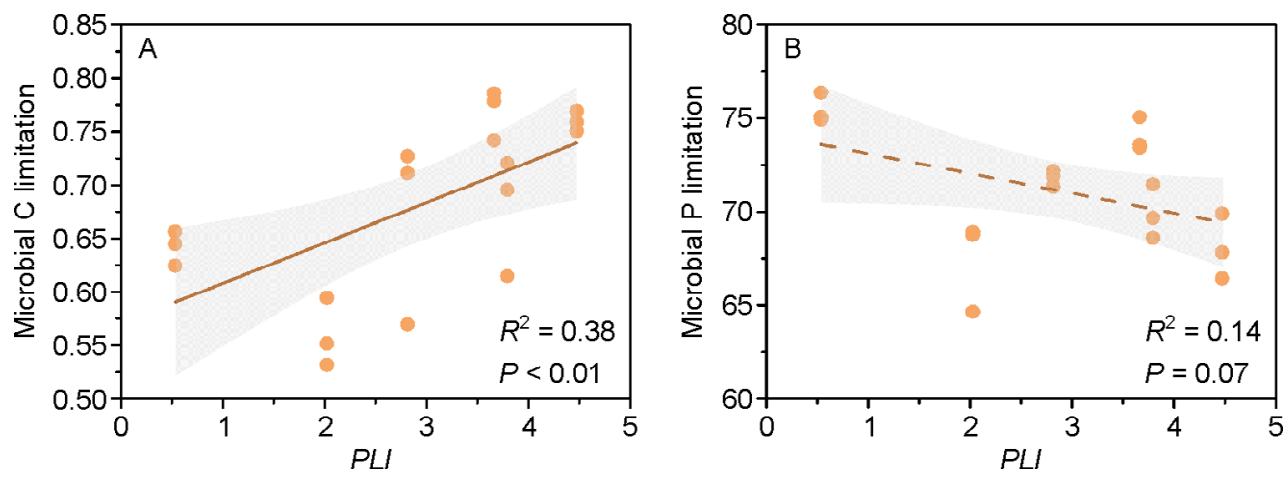

Fig. 7 Relationships of the $P L I$ (pollution load index) with microbial $C$ limitation (A) and $\mathrm{P}$ limitation (B). The gray areas are the 95\% confidence interval of the models. 


\section{References}

Alkorta, I., Aizpurua, A., Riga, P., Albizu, I., Amezaga, I., Garbisu, C., 2003. Soil enzyme activities as biological indicators of soil health. Reviews on Environmental Health 18, 65-73.

Allison, S.D., Wallenstein, M.D., Bradford, M.A., 2010. Soil-carbon response to warming dependent on microbial physiology. Nature Geoscience 3, 336-340.

Aponte, H., Medina, J., Butler, B., Meier, S., Cornejo, P., Kuzyakov, Y. 2020a. Soil quality indices for metal(loid) contamination: An enzymatic perspective. Land Degradation \& Development 31, 2700-2719.

Aponte, H., Meli, P., Butler, B., Paolini, J., Matus, F., Merino, C., Cornejo, P., Kuzyakov, Y., 2020b. Meta-analysis of heavy metal effects on soil enzyme activities. Science of the Total Environment 737, 12.

Baumann, K., Dignac, M.F., Rumpel, C., Bardoux, G., Sarr, A., Steffens, M., Maron, P.A., 2012. Soil microbial diversity affects soil organic matter decomposition in a silty grassland soil. Biogeochemistry 114, 201-212.

Beattie, R.E., Henke, W., Campa, M.F., Hazen, T.C., McAliley, L.R., Campbell, J.H., 2018. Variation in microbial community structure correlates with heavy-metal contamination in soils decades after mining ceased. Soil Biology \& Biochemistry 126, 57-63.

Beiyuan, J., Fang, L., Chen, H., Li, M., Liu, D., Wang, Y., 2020. Nitrogen of EDDS enhanced removal of potentially toxic elements and attenuated their oxidative stress in a phytoextraction process. Environmental Pollution 268, 115719

Berg, J., Brandt, K.K., Al-Soud, W.A., Holm, P.E., Hansen, L.H., Sorensen, S.J., Nybroe, O., 2012. Selection for Cu-tolerant bacterial communities with altered composition, but unaltered richness, via long-term $\mathrm{Cu}$ exposure. Applied and Environmental Microbiology 78, 7438-7446.

Blagodatskaya, E., Blagodatsky, S., Anderson, T.H., Kuzyakov, Y., 2014. Microbial growth and carbon use efficiency in the rhizosphere and root-free soil. PLoS One 9, 9.

Boamponsem, L.K., Adam, J.I., Dampare, S.B., Nyarko, B.J.B., Essumang, D.K., 2010. Assessment of atmospheric heavy metal deposition in the Tarkwa gold mining area of Ghana using epiphytic lichens. Nuclear Instruments \& Methods in Physics Research. Section B, Beam Interactions with Materials and Atoms 268, 1492 1501.

Bore, E.K., Apostel, C., Halicki, S., Kuzyakov, Y., Dippold, M.A., 2017. Soil microorganisms can overcome respiration inhibition by coupling intra- and extracellular metabolism: C-13 metabolic tracing reveals the mechanisms. ISME Journal 11, 1423-1433.

Bremner J., Mulvaney C., 1996. Nitrogen-total. Methods of soil analysis chemical methods part, 72:532-535.

Cang, L., Zhou, D.M., Wang, Q.Y., Wu, D.Y., 2009. Effects of electrokinetic treatment of a heavy metal contaminated soil on soil enzyme activities. Journal of Hazardous Materials 172, 1602 1607.

Chander, K., Dyckmans, J., Joergensen, R.G., Meyer, B., Raubuch, M., 2001. Different sources of heavy metals and their long-term effects on soil microbial properties. Biology and Fertility of Soils 34 , 241-247.
Chen, L., Feng, Q., Li, C., Wei, Y., Zhao, Y., Feng, Y., Zheng, H., Li, F., $\mathrm{Li}, \mathrm{H}$., 2017. Impacts of aquaculture wastewater irrigation on soil microbial functional diversity and community structure in arid regions. Scientific Reports 7, 7.

Choppala, G., Saifullah, N., Bolan, S., Bibi, M., Iqbal, Z., Rengel, A., Kunhikrishnan, N., Ashwath, Y.S., Ok, 2014. Cellular mechanisms in higher plants governing tolerance to cadmium toxicity. Critical Reviews in Plant Sciences 33, 374-391.

Cui, Y., Fang, L., Guo, X., Han, F., Ju, W., Ye, L., Wang, X., Tan, W., Zhang, X., 2019. Natural grassland as the optimal pattern of vegetation restoration in arid and semi-arid regions: Evidence from nutrient limitation of soil microbes. Science of the Total Environment 648, 388-397.

Cui, Y., Fang, L., Guo, X., Wang, X., Zhang, Y., Li, P., Zhang, X., 2018. Ecoenzymatic stoichiometry and microbial nutrient limitation in rhizosphere soil in the arid area of the northern Loess Plateau, China. Soil Biology \& Biochemistry 116, 11-21.

Diao, Z., 2016. Effects of exogenous heavy metals on soil nutrients and microbial activity of different types. Dissertation. Northwest A\&F University (in Chinese).

Duan, C., Fang, L., Yang, C., Chen, W., Cui, Y., Li, S., 2018. Reveal the response of enzyme activities to heavy metals through in situ zymography. Ecotoxicology and Environmental Safety 156, 106115.

Fang, L., Liu, Y., Tian, H., Chen, H., Wang, Y., Huang, M., 2017. Proper land use for heavy metal-polluted soil based on enzyme activity analysis around a $\mathrm{Pb}-\mathrm{Zn}$ mine in Feng County, China. Environmental Science and Pollution Research International 24, 28152-28164.

Frey, S.D., Gupta, V., Elliott, E.T., Paustian, K., 2001. Protozoan grazing affects estimates of carbon utilization efficiency of the soil microbial community. Soil Biology \& Biochemistry 33, 1759-1768.

German, D.P., Weintraub, M.N., Grandy, A.S., Lauber, C.L., Rinkes, Z. L., Allison, S.D., 2011. Optimization of hydrolytic and oxidative enzyme methods for ecosystem studies. Soil Biology \& Biochemistry 43, 1387-1397.

Golebiewski, M., Deja-Sikora, E., Cichosz, M., Tretyn, A., Wrobel, B., 2014. 16S rDNA pyrosequencing analysis of bacterial community in heavy metals polluted soils. Microbial Ecology 67, 635-647.

Hu, X.F., Jiang, Y., Shu, Y., Hu, X., Liu, L., Luo, F., 2014. Effects of mining wastewater discharges on heavy metal pollution and soil enzyme activity of the paddy fields. Journal of Geochemical Exploration 147, 139-150.

Jin, Y., Luan, Y., Ning, Y., Wang, L., 2018. Effects and mechanisms of microbial remediation of heavy metals in Soil: A Critical Review. Applied Sciences-Basel 8, 1336

Jones, D.L., Kielland, K., Sinclair, F.L., Dahlgren, R.A., Newsham, K. K., Farrar, J.F., Murphy, D.V., 2009. Soil organic nitrogen mineralization across a global latitudinal gradient. Global Biogeochemical Cycles 23, 23.

Ju, W., Liu, L., Fang, L., Cui, Y., Duan, C., Wu, H., 2019. Impact of coinoculation with plant-growth-promoting rhizobacteria and rhizobium on the biochemical responses of alfalfa-soil system in copper contaminated soil. Ecotoxicology and Environmental Safety 167, 218-226.

Kandeler, E., Tscherko, D., Bruce, K.D., Stemmer, M., Hobbs, P.J., 
Bardgett, R.D., Amelung, W., 2000. Structure and function of the soil microbial community in microhabitats of a heavy metal polluted soil. Biology and Fertility of Soils 32, 390-400.

Khan, S., Cao, Q., Hesham, A.E.L., Xia, Y., He, J.Z., 2007. Soil enzymatic activities and microbial community structure with different application rates of $\mathrm{Cd}$ and $\mathrm{Pb}$. Journal of Environmental Sciences (China) 19, 834-840.

Komy, Z.R., 1995. Comparative-study of titrimetric and gravimetric methods for the determination of organic-carbon in soils. International Journal of Environmental Analytical Chemistry 60, 41-47.

Kuperman, R.G., Carreiro, M.M., 1997. Soil heavy metal concentrations, microbial biomass and enzyme activities in a contaminated grassland ecosystem. Soil Biology \& Biochemistry 29, 179-190.

Li, X., Meng, D., Li, J., Yin, H., Liu, H., Liu, X., Cheng, C., Xiao, Y., Liu, Z., Yan, M., 2017. Response of soil microbial communities and microbial interactions to long-term heavy metal contamination. Environmental Pollution 231, 908-917.

Lin, Y., Ye, Y., Hu, Y., Shi, H., 2019. The variation in microbial community structure under different heavy metal contamination levels in paddy soils. Ecotoxicology and Environmental Safety 180, 557-564.

Liu, G., Tao, L., Liu, X., Hou, J., Wang, A., Li, R., 2013. Heavy metal speciation and pollution of agricultural soils along Jishui River in non-ferrous metal mine area in Jiangxi Province, China. Journal of Geochemical Exploration 132, 156-163.

Markowicz, A., Cycon, M., Piotrowska-Seget, Z., 2016. Microbial community structure and diversity in long-term hydrocarbon and heavy metal contaminated soils. International Journal of Environmental Research 10, 321-332.

Mierzwa-Hersztek, M., Gondek, K., Klimkowicz-Pawlas, A., Baran, A., Bajda, T., 2018. Sewage sludge biochars management-ecotoxicity, mobility of heavy metals, and soil microbial biomass. Environmental Toxicology and Chemistry 37, 1197-1207.

Moorhead, D.L., Rinkes, Z.L., Sinsabaugh, R.L., Weintraub, M.N., 2013. Dynamic relationships between microbial biomass, respiration, inorganic nutrients and enzyme activities: informing enzymebased decomposition models. Frontiers in Microbiology 4, 4.

Moorhead, D.L., Sinsabaugh, R.L., Hill, B.H., Weintraub, M.N., 2016. Vector analysis of ecoenzyme activities reveal constraints on coupled C, N and P dynamics. Soil Biology \& Biochemistry 93, 1-7.

Oliveira, A., Pampulha, M.E., 2006. Effects of long-term heavy metal contamination on soil microbial characteristics. Journal of Bioscience and Bioengineering 102, 157-161.

Page, A.L., Miller, R.H., Keeney, D.R., 1982. Methods of Soil Analysis: Chemical and Microbiological Properties. American Society of Agronomy, Soil Science Society of America, Madison, Wisconsin.

Peng, X., Wang, W., 2016. Stoichiometry of soil extracellular enzyme activity along a climatic transect in temperate grasslands of northern China. Soil Biology \& Biochemistry 98, 74-84.

Saiya-Cork, K.R., Sinsabaugh, R.L., Zak, D.R., 2002. The effects of long term nitrogen deposition on extracellular enzyme activity in an Acer saccharum forest soil. Soil Biology \& Biochemistry 34, 1309 1315.

Sheik, C.S., Mitchell, T.W., Rizvi, F.Z., Rehman, Y., Faisal, M., Hasnain, S., Mclnerney, M.J., Krumholz, L.R., 2012. Exposure of soil microbial communities to chromium and arsenic alters their diversity and structure. PLoS One 7, 7.

Shen, F., Liao, R., Ali, A., Mahar, A., Guo, D., Li, R., Sun, X., Awasthi, M.K., Wang, Q., Zhang, Z., 2017. Spatial distribution and risk assessment of heavy metals in soil near a $\mathrm{Pb} / \mathrm{Zn}$ smelter in Feng County, China. Ecotoxicology and Environmental Safety 139, 254 262.

Sinsabaugh, R.L., Hill, B.H., Shah, J.J.F., 2009. Ecoenzymatic stoichiometry of microbial organic nutrient acquisition in soil and sediment. Nature 462(7274), 795-798.

Stuczynski, T.I., McCarty, G.W., Siebielec, G., 2003. Response of soil microbiological activities to cadmium, lead, and zinc salt amendments. Journal of Environmental Quality 32, 1346-1355.

Tang, J., Zhang, J., Ren, L., Zhou, Y., Gao, J., Luo, L., Yang, Y., Peng, Q., Huang, H., Chen, A., 2019. Diagnosis of soil contamination using microbiological indices: A review on heavy metal pollution. Journal of Environmental Management 242, 121-130.

Tripathy, S., Bhattacharyya, P., Mohapatra, R., Som, A., Chowdhury, D., 2014. Influence of different fractions of heavy metals on microbial ecophysiological indicators and enzyme activities in century old municipal solid waste amended soil. Ecological Engineering 70, 25-34.

Vanremortel, R., Shields, D., 1993. Comparison of clod and core methods for determination of soil bulk-density. Communications in Soil Science and Plant Analysis 24, 2517-2528.

Wang, F., Yao, J., Tian, L., Zhou, Y., Chen, H., Chen, H., Gai, N., Chen, Y., Zhuang, R., Zaray, G., Maskow, T., Bramanti, E., 2008. Microcalorimetric investigation of the toxic action of ammonium ferric(III) sulfate on the metabolic activity of pure microbes. Environmental Toxicology and Pharmacology 25, 351-357.

Wang, X., Cui, Y., Zhang, X., Ju, W., Duan, C., Wang, Y., Fang, L., 2020. A novel extracellular enzyme stoichiometry method to evaluate soil heavy metal contamination: Evidence derived from microbial metabolic limitation. Science of the Total Environment 738, 139709.

Wang, Y., Guo, J., Liu, R., 2001. Biosorption of heavy metals by bacteria isolated from activated sludge. Huan Jing Ke Xue 22, 72 75.

Wyszkowska, J., Kucharski, J., Lajszner, W., 2006. The effects of copper on soil biochemical properties and its interaction with other heavy metals. Polish Journal of Environmental Studies 15, 927934.

Xian, Y., Wang, M., Chen, W., 2015. Quantitative assessment on soil enzyme activities of heavy metal contaminated soils with various soil properties. Chemosphere 139, 604-608.

Xiao, R., Shen, F., Du, J., Li, R., Lahori, A.H., Zhang, Z., 2018. Screening of native plants from wasteland surrounding a $\mathrm{Zn}$ smelter in Feng County China, for phytoremediation. Ecotoxicology and Environmental Safety 162, 178-183.

Xiao, X.Y., Wang, M.W., Zhu, H.W., Guo, Z.H., Han, X.Q., Zeng, P., 2017. Response of soil microbial activities and microbial community structure to vanadium stress. Ecotoxicology and Environmental Safety 142, 200-206.

Xu, Y., Seshadri, B., Bolan, N., Sarkar, B., Ok, Y.S., Zhang, W., Rumpel, C., Sparks, D., Farrell, M., Hall, T., Dong, Z., 2019. Microbial functional diversity and carbon use feedback in soils as affected by heavy metals. Environment International 125, 478- 
488.

Xu, Y., Seshadri, B., Sarkar, B., Wang, H., Rumpel, C., Sparks, D., Farrell, M., Hall, T., Yang, X., Bolan, N., 2018. Biochar modulates heavy metal toxicity and improves microbial carbon use efficiency in soil. Science of the Total Environment 621, 148-159.

Yang, J., Yang, F., Yang, Y., Xing, G., Deng, C., Shen, Y., Luo, L., Li,
B., Yuan, H., 2016. A proposal of "core enzyme" bioindicator in long-term $\mathrm{Pb}-\mathrm{Zn}$ ore pollution areas based on topsoil property analysis. Environmental Pollution 213, 760-769.

Zhang, J., Wang, L.H., Yang, J.C., Liu, H., Dai, J.L., 2015. Health risk to residents and stimulation to inherent bacteria of various heavy metals in soil. Science of the Total Environment 508, 29-36. 